$$
\begin{aligned}
& {\left[\gamma^{\mu}\left(i \partial_{\mu}+e A_{\mu}\right)-x+\left\{S^{\mu_{v}} f_{\mu_{\nu}}+\ldots+\right.\right.} \\
& \left.\left.\quad S^{\mu_{\nu} \sigma} \cdots \rho \frac{\partial^{n} f_{\mu_{\nu}}}{\partial x^{\sigma} \ldots \partial x^{\rho}}+\ldots\right\}\right] \psi=0,
\end{aligned}
$$

where $f_{\mu_{\nu}}=\partial_{\mu} A_{\nu}-\partial_{\nu} A_{\mu}$ give the field components, and the infinite series in curly brackets represents the additional contributions to the Hamiltonian from the multipole interactions of the particle with the electromagnetic field. Such an equation would describe an electron which is a superposition of a point charge, a point dipole and point multipoles to all orders, and one might expect it to describe a finite electron. The additional terms are negligible when the field $f_{\mu \nu}$ varies slowly, but will be important for fields of high frequency.

University of Ceylon, C. JAyaratnam Eliezer

Colombo.

Aug. 16.

' Eliezer, C. J., Proc. Roy. Soc.. A, 194, 543 (1948); Proc. Camb. Phil. Soc., 46, 199 (1950).

\section{Polarographic Investigation of the Antigen-Antibody Reaction}

UsING azo-protein as antigen, preliminary experiments were carried out to investigate whether the polarographic method could be used for a quantitative determination of immunological reactions.

Azo-protein was prepared by coupling egg albumin with diazotized $p$-aminobenzoic acid following the method of Landsteiner ${ }^{1}$. For polarographic investigation the product from $1 \mathrm{gm}$. of egg albumin was dissolved in $80 \mathrm{ml}$. of acetate-phosphate-borate buffer $^{2}, p H 7 \cdot 3$. Allowing for an 80 per cent reaction yield, this gives an approximately 1 per cent solution of azo-protein.

A polarographic step was obtained between 240 and $440 \mathrm{mV}$..vs. the saturated calomel cell. The step was not very well defined but could be determined (Table 1) and reproduced with reasonable accuracy (approximately $\pm \mathbf{5}$ per cent). Within this limit of accuracy, the step height was proportional to concentration, as we have found in experiments using buffer as diluent (Table 2).

Further experiments showed that the azo-protein solutions used were stable for several weeks under laboratory conditions.

Specific antiserum was prepared by giving rabbits a series of six injections at seven-day intervals. Each injection consisted of $5 \mathrm{ml}$. of approximately 1 per

\begin{tabular}{|c|c|c|}
\hline $\begin{array}{l}\text { Id measured } \\
\left(\text { amp. } \times 10^{-7}\right)\end{array}$ & $\begin{array}{c}\text { Id average } \\
\left(\text { amp. } \times 10^{-7}\right)\end{array}$ & $\begin{array}{l}\text { Deviation } \\
\text { (per cent) }\end{array}$ \\
\hline $\begin{array}{l}3.06 \\
3.04 \\
2.99\end{array}$ & $3 \cdot n 33$ & $\begin{array}{l}+1 \cdot 0 \\
+0.3 \\
-1.3\end{array}$ \\
\hline
\end{tabular}

TABISE 1

\begin{tabular}{|c|c|c|c|}
\hline Dilution & $\begin{array}{l}\text { Id measured } \\
\left(\text { amp. } \times 16^{-7}\right)\end{array}$ & $\begin{array}{l}\text { Id mean value* } \\
\left(\text { amp. } \times 10^{-7}\right)\end{array}$ & $\begin{array}{l}\text { Deviation from } \\
\text { mean value } \\
\text { (per cent) }\end{array}$ \\
\hline $\begin{array}{c}0 \\
1 \\
1: 1 \\
1: 3 \\
1: 7\end{array}$ & $\begin{array}{l}3 \cdot 74 \\
2 \cdot 17 \\
1 \cdot 29 \\
0 \cdot 78\end{array}$ & $\begin{array}{l}3 \cdot 87 \\
2 \cdot 12 \\
1.24 \\
0.81\end{array}$ & $\begin{array}{r}-3.4 \\
+2.4 \\
+4.0 \\
-2.5\end{array}$ \\
\hline
\end{tabular}

TABLE 2

* The mean value was obtained from a calibration curve plotting concentration against current. cent azo-protein solution. The rabbits were bled two weeks after the final injection, the blood clotted and the serum separated by" centrifugation. Precipitation tests showed the serum to be active, and it gave best results by reaction with a 1 per cent solution of antigen with diluted antiserum (1:4), both in buffer.

Experiments were then carried out to examine the effect of the addition of specific and unspecific sera upon the azo-protein polarographic step. Unspecific serum merely acted as a normal diluent, whereas the addition of unspecific antiserum under the same conditions of concentration, etc., sharply decreased the step height.

Table 3 shows the typical results obtained with two out of a considerable number of specific antisera examined.

\begin{tabular}{|c|c|c|c|c|c|}
\hline $\begin{array}{c}\text { Volume of } \\
\text { unspecific } \\
\text { serum } \\
\text { added per } \\
\text { ml. of azo- } \\
\text { protein }\end{array}$ & $\begin{array}{l}\text { Volume of } \\
\text { anti- } \\
\text { serum } \\
\text { No. } 1 \\
\text { added per } \\
\text { ml. of azo- } \\
\text { protein }\end{array}$ & $\begin{array}{l}\text { Volume of } \\
\text { anti- } \\
\text { serum } \\
\text { No. } 2 \\
\text { added per } \\
\text { ml. of azo- } \\
\text { protein }\end{array}$ & $\begin{array}{c}J d \\
\text { meas- } \\
\text { ured } \\
\text { (amp. } \\
\left.\times 10^{-7}\right)\end{array}$ & $\begin{array}{c}\text { Id mean } \\
\text { value (de- } \\
\text { rived on } \\
\text { the basis } \\
\text { of dilution) } \\
\text { (amp. } \\
\left.\times 10^{-7}\right)\end{array}$ & $\begin{array}{l}\text { Differ- } \\
\text { ence } \\
\text { from } \\
\text { mean } \\
\text { value } \\
\text { (per } \\
\text { cent) }\end{array}$ \\
\hline $\begin{array}{c}1 \stackrel{0}{\mathrm{ml}} . \\
2 \mathrm{ml} .\end{array}$ & $\begin{array}{c}0 \\
1 \mathrm{ml} . \\
2 \mathrm{ml} .\end{array}$ & $\begin{array}{c}0 \\
1 \mathrm{ml} . \\
2 \mathrm{ml} .\end{array}$ & $\begin{array}{l}4 \cdot 06 \\
2 \cdot 03 \\
1 \cdot 52 \\
1 \cdot 58 \\
1 \cdot 39 \\
0 \cdot 90 \\
0 \cdot 96\end{array}$ & $\begin{array}{l}4 \cdot 02 \\
2 \cdot 02 \\
2 \cdot 02 \\
2 \cdot 02 \\
1 \cdot 35 \\
1 \cdot 35 \\
1 \cdot 35\end{array}$ & $\begin{array}{l}+1.0 \\
+0.5 \\
+24.8 \\
-21.8 \\
+\quad 3.0 \\
-33.3 \\
-28.9\end{array}$ \\
\hline
\end{tabular}

TABLE :3

From these results it is clear that the antigenantibody reaction can be detected and measured by polarographic procedure. Work is in progress to perfect the quantitative aspect of the method, with the object of applying polarography to the study of the kinetics of the antigen-antibody reaction.

$$
\text { B. BREYER }
$$

F. J. RADCLTFF

Physico-Chemical Laboratory,

Faculty of Agriculture,

University of Sydney. Sept. 5.

${ }^{1}$ Landsteiner, K., and van der Scheer, J., J. Exp. Med., 56, 404 (1932). ${ }^{2}$ Prideaux and Ward, J. Chem. Soc., 125, 426 (1924).

\section{Reversed-Phase Partition Chromatography}

IN the course of experiments involving the use of powdered glass as a carrier in partition chromatography, we have found that it is possible to prepare columns having as the stationary phase either an aqueous liquid or a water-immiscible organic solvent. Columns in which a stationary aqueous phase is distributed on glass have already been applied to the fractionation of the alkaloids of Punica Granatum ${ }^{1}$. We now find that satisfactory reversed-phase columns may be prepared by the following procedure. Chloroform (8 c.c.) is shaken thoroughly with 'Pyrex' glass (80 gm.) in No. 100 powder. The 'wetted' glass is tipped into water (100 c.c.), previously saturated with chloroform, and the mixture is mechanically stirred at moderate speed with an upflow stirrer until all globules of chloroform are disintegrated; the slurry is poured into the chromatogram tube and again thoroughly shaken. The column is allowed to pack spontaneously by draining in a vertical position, and the top is tamped by gentle pressure on a disk of filter-paper placed above the packed column. Similar columns can be prepared using benzene instead of 